\title{
Annotation
}

\section{Pathogen or commensal?}

The distinction between bacterial commensals and pathogens has never been sharp in the perinatal period. At other ages commensals are mainly to be found on the skin and in the upper respiratory, gastrointestinal, and lower genitourinary tracts. They and other so-called nonpathogens of the environment may assert on occasions a dangerous and sometimes lethal dominance in the fetus and newborn, which is foreign to their role of peaceful coexistence with healthy older children and adults. If however there is impaired host defence, the body commensals may move away from their usual place of residence to invade other tissues; and it seems likely that it is a similar failure to mount the necessary immune and inflammatory responses to fight infection which accounts for the newborn's peculiar susceptibility to an enormously wide variety of bacteria. ${ }^{1}$ A greater awareness of the opportunism of the 'harmless' variety perhaps came as incubators and other apparatus containing humidification units were introduced into newborn nurseries on a large scale, for a plethora of weird microbes flourished in the water there. ${ }^{2}$ Generic names such as Pseudomonas, Acinetobacter, Moraxella, Alkaligenes and Edwardsiella among others soon found their way into paediatricians' vocabulary; and paediatricians began to realise that the deficiencies of their sterilisation procedures could cause fatal sepsis in their immunologically innocent patients.

Bacterial commensals of the vagina may also pose special problems for the infant, and group $B$ streptococcal infection is a case in point. In a recent issue of this journal the isolation of Corynebacterium kutscheri in pure culture from the umbilical cord, fetal membranes, rectum, nose, throat, eye, and external ear of an immature infant was described. ${ }^{3}$ It was also possible to demonstrate numbers of organisms within the cord and membranes, and the cellular response they evoked. The 980-g infant was ill for several days after birth, and radio-opacities in the chest were thought to be consistent with a pneumonitis. As she recovered, and the organism was not isolated from her tracheal aspirate, proof that $C$. kutscheri caused the illness was lacking, although the circumstances certainly suggested it. Diphtheroids are recognised as part of normal vaginal flora, but rarely if ever are, they reported in pure culture, as Fitter et al.$^{3}$ pointed out.

Chorioamnionitis and funisitis, such as they described, were the subjects of careful work some years ago, ${ }^{4-5}$ and have recently been re-examined in a series of publications by Naeye et al. ${ }^{6-13}$ They believe amniotic fluid infection syndrome to be the leading cause of perinatal mortality; and define it as congenital pneumonia associated with inflammation of the extraplacental membranes, umbilical cord and chorionic plate of the placenta, with intact membranes at the beginning of labour. They state that the condition in most cases, is caused by bacteria ascending from the vagina and that invasion of membranes near the cervical os leading to a localised chorioamnionitis is a fairly common event. Mycoplasma sp. may be responsible in a small proportion of cases. ${ }^{9}$ The condition has its peak between 20 and 26 weeks of gestation-when it may be associated with premature rupture of the membranes and premature labour, and repeated fetal lossesdrops to its lowest between 32 and 37 weeks, and then increases again. ${ }^{12}$ Studies in New York City showed it to have a direct association with poverty, ${ }^{6}$ and to be more common in blacks than in Puerto Ricans and whites. Parallel studies in Ethiopia have shown the same relation with poverty. They have also shown an interesting inverse connection between water usage and the amniotic infection syndrome, with a low incidence of the condition when the use of water is high, even in the poorest sections of the community, though as the use to which the water had been put was unknown, no conclusions could be drawn. ${ }^{10}$ Amniotic fluid is now known to have antimicrobial properties. A low molecular weight fraction consisting of a family of polypeptides whose bactericidal activity is zinc-dependent has been isolated. ${ }^{14-15}$ Antimicrobial activity was found to be absent at term in $75 \%$ of 53 Ethiopian women studied, and undernutrition was suggested as the most likely cause. ${ }^{11}$

There are some fundamental difficulties in regarding many cases of congenital pneumonia as a true infection as Naeye et al. do, for often the histological picture seems to represent a passive aspiration of maternal leucocytes into the air spaces, together with squames and amniotic debris. ${ }^{16-17}$ There is rarely evidence of infiltration or destruction 
of bronchopulmonary tissue, although this may occur in the fetal membranes with the accompanying chorioamnionitis. Leucocytes found in the gastric aspirate shortly after birth following prolonged membrane rupture have certainly been proved maternal in origin. ${ }^{18}$ Furthermore the histological findings in the lungs in the often devastating intrapartum infection caused by group B $\beta$-haemolytic streptococcus may be very different. ${ }^{19}$ Many babies with congenital pneumonia, especially in the Ethiopian series, were stillborn. There was a pronounced fall in deaths from pneumonia in this country between the two National Perinatal Mortality Surveys of 1958 and 1970. Thus perinatal deaths from pneumonia fell from $1 \cdot 3 / 1000$ to $0 \cdot 1 / 1000$ total births, and first week deaths from $1 \cdot 0 / 1000$ to $0 \cdot 1 / 1000$ livebirths. ${ }^{20}$ Although it is not certain to what extent 'congenital pneumonia' as defined by Naeye ${ }^{8}$ took part in this decrease, one might suppose that many infants with amniotic fluid infection syndrome have died an asphyxial death in the past, and that improved antenatal care with careful watchfulness during labour, and improved resuscitation at birth will allow many of them to live. Chorioamnionitis is certainly a fairly common condition, and may exert its greatest harm by its association with premature labour. But there is also evidence not confined to necropsy material, ${ }^{21-22}$ to show that infants may come from an infected intrauterine environment unscathed; few would deny however that their liability to subsequent sepsis is greater.

\section{References}

1 Miller M E. Host defenses in the human neonate. Monographs in neonatology. New York: Grune and Stratton, 1978.

2 Editorial: Water bugs in the bassinet. Am J Dis Child 1961 ; 101 : 273-7.

3. Fitter W F, de Sa D J, Richardson H. Chorioamnionitis and funisitis due to Corynebacterium kutscheri. Arch Dis Child 1979; 54: 710-2.

- Benirschke K, Clifford S H. Intrauterine bacterial infection of the newborn infant: frozen sections of the cord as an aid to early detection. $J$ Pediatr $1959 ; 54: 11-8$.

5 . Blanc W A. Pathways of fetal and early neonatal infection. Viral placentitis, bacterial and fungal chorioamnionitis. $J$ Pediatr 1961; 59: 473-96.
- Naeye $\mathbf{R}$ L, Blanc W A. Relation of poverty and race to antenatal infection. $N$ Engl J Med 1970; 283: 555-60.

7 Naeye R L, Blanc W A. Unfavorable outcome of pregnancy: repeated losses. Am J Obstet Gynecol 1973; 116: 1133-7.

8 Naeye R L, Dellinger W S, Blanc W A. Fetal and maternal features of antenatal bacterial infections. J Pediatr 1971; 79: 733-9.

- Tafari N, Ross S, Naeye R L, Judge D M, Marboe C. Mycoplasma T strains and perinatal death. Lancet 1976; 1: 108-9.

10 Naeye R L, Tafari N, Judge D, Gilmour D, Marboe C. Amniotic fluid infections in an African city. $J$ Pediatr 1977; 90: 965-70.

11 Tafari N, Ross S M, Naeye R L, Galask R P, Zaar B. Failure of bacterial growth inhibition by amniotic fluid. Am J Obstet Gynecol 1977; 128: 187-9.

12 Naeye R L, Peters E C. Amniotic fluid infections with intact membranes leading to perinatal death: a prospective study. Pediatrics $1978 ; 61$ : 171-7.

13 Naeye R L, Tafari N, Judge D, Marboe C C. Twins: causes of perinatal death in 12 United States cities and one African city. Am J Obstet Gynecol 1978; 131 : 267-72.

14 Schlievert P, Johnson W, Galask R P. Isolation of a lowmolecular-weight antibacterial system from human amniotic fluid. Infect Immun 1976; 14: 1156-66.

15 Sachs B P, Stern C M. Activity and characterisation of a low molecular fraction present in human amniotic fluid with broad spectrum antibacterial activity. Br J Obstet Gynaecol 1979; 86: 81-6.

16 Osborn G R. Letter: Congenital pneumonia. Lancet 1962; 1 : 275.

17 Davies P A, Aherne W. Congenital pneumonia. Arch Dis Child 1962; 37: 598-602.

18 Vasan U, Lim D M, Greenstein R M, Raye J R. Origin of gastric aspirate polymorphonuclear leukocytes in infants born after prolonged rupture of membranes. J Pediatr 1977; 91: 69-72.

19 Katzenstein A-L, Davis C, Braude A. Pulmonary changes in neonatal sepsis due to group B $\beta$-hemolytic streptococcus: relation to hyaline membrane disease. J Infect Dis 1976; 133: 430-5.

20 Claireaux A. Stillbirths and first week deaths. In: Chamberlain R, ed. British births 1970, vol. 1, The first week of life. London: Heinemann Medical, 1975: 235-53.

21 Shurin P A, Alpert S, Rosner B, et al. Chorioamnionitis and colonization of the newborn infant with genital mycoplasmas. $N$ Engl $J$ Med 1975; 293: 5-8.

22 Keenan W J, Steichen J J, Mahmood K, Altshuler G. Placental pathology compared with clinical outcome. A retrospective blind review. Am J Dis Child 1977; 131 : 1224-7.

Pamela A Davies

Department of Paediatrics and Neonatal Medicine, Hammersmith Hospital, Du Cane Road, London W12 OHS 